\title{
Potential impacts of the invasive species Corbicula fluminea on the survival of glochidia
}

\author{
Vanessa Modesto ${ }^{\mathrm{a}, \mathrm{b}, *}$, Paulo Castro ${ }^{\mathrm{a}}$, Manuel Lopes-Lima ${ }^{\mathrm{b}, \mathrm{c}}$, Carlos Antunes $^{\mathrm{b}, \mathrm{d}}$, Martina Ilarri ${ }^{\mathrm{b}}$, Ronaldo Sousa ${ }^{\mathrm{a}}$ \\ a CBMA - Centre of Molecular and Environmental Biology, Department of Biology, University of Minho, Campus de Gualtar, 4710-057 Braga, Portugal

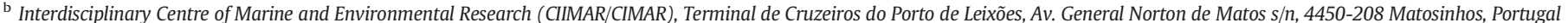 \\ c CIBIO/InBIO - Research Center in Biodiversity and Genetic Resources, University of Porto, 4485-661 Vairão, Portugal \\ d Aquamuseu do Rio Minho, Parque de Lazer do Castelinho, 4920-290 Vila Nova de Cerveira, Portugal
}

\section{H I G H L I G H T S}

- C. fluminea influence on the mortality of native mussels glochidia was evaluated.

- Glochidia mortality was highly dependent on C. fluminea density and time.

- Glochidia mortality was influenced by C. fluminea activities.

- High C. fluminea densities may be detrimental for freshwater mussel conservation.

\section{G R A P H I C A L A B S T R A C T}

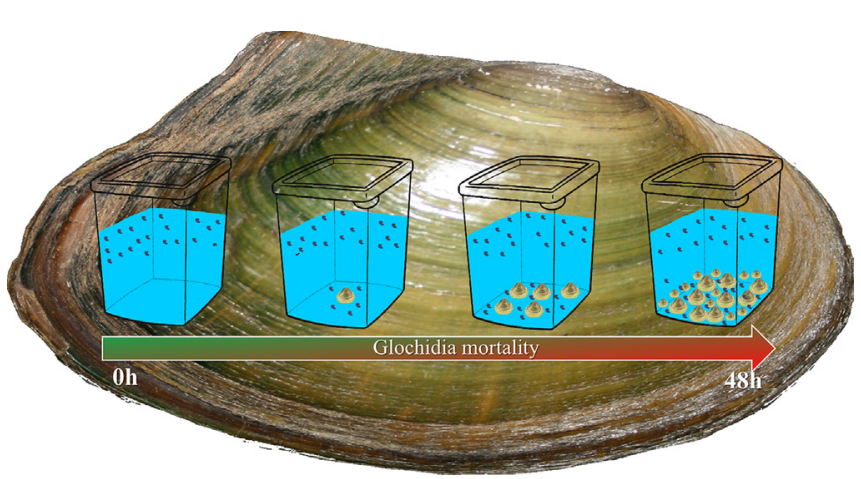

\section{A B S T R A C T}

Freshwater mussels (Bivalvia, Unionida) are one of the most imperilled faunal groups globally, being the introduction of invasive species a possible major mechanism of threat. The Asian clam Corbicula fluminea is a problematic invasive species in aquatic ecosystems and can impair the survival of parasitic larvae (glochidia) of native freshwater mussels. However, this possible mechanism of threat remains speculative and to date very few studies addressed quantitatively this issue. In order to cover this gap, we have performed a series of manipulative laboratory studies to assess how distinct densities of $C$. fluminea can affect the survival of glochidia after 6,12, 24 and $48 \mathrm{~h}$ of exposure, using larvae of the native freshwater mussel Anodonta anatina. Our results suggest an increase in mortality of $A$. anatina glochidia with an increase in density of $C$. fluminea. Two main mechanisms may possibly explain our results: 1 ) the high filtration capacity of $C$. fluminea that can contribute to the mortality of glochidia due to the mechanical damage of their fragile shells when passing by siphons and/or digestive tract of $C$. fluminea and 2) the high excretion capacity of $C$. fluminea that can lead to mortality of glochidia due to increase in ammonia concentration. Mortality of glochidia was also time dependent with higher values registered after $48 \mathrm{~h}$. This work is one of the first showing the influence of $C$. fluminea density on the survival of glochidia, being filtration (and consequent passage in the digestive tract) and biodeposition the main potential mechanisms explaining overall mortality. These results also suggest that sites with high densities of $C$. fluminea may be highly detrimental for the conservation of freshwater mussels, potentially impairing the survival of glochidia and negatively affecting the recruitment of juveniles.

C 2019 Published by Elsevier B.V.

\footnotetext{
* Corresponding author at: CBMA - Centre of Molecular and Environmental Biology, Department of Biology, University of Minho, Campus de Gualtar, $4710-057$ Braga, Portugal. E-mail address: vane.modesto@gmail.com (V. Modesto).
} 


\section{Introduction}

Over the last decades the interest about species with a complex lifecycle has been increasing among biologists (Allen et al., 2018; Combes, 1997; Rauch et al., 2005; Roughgarden et al., 1988; Stoks and CórdobaAguilar, 2012; Wilbur, 1980). Usually, species with complex life-cycle encompass organisms that undergo metamorphosis, together with its associated changes on morphology, physiology and behaviour, at least once in their life history (Hadfield, 2000; Hyeun-Ji and Johansson, 2015; Rowe and Ludwig, 1991; Werner, 1988). Of the $>80 \%$ of animals that undergo metamorphosis (Werner, 1988; Wilson and Krause, 2012), many are parasitic at least in some life stages (Galetti et al., 2018; Stoks and Córdoba-Aguilar, 2012; Wilbur, 1980).

Contrary to terrestrial invertebrates, where larvae are generally specialized on growth and adults on dispersion, parasitic aquatic invertebrates may have a high dispersal capacity during their larval stage, whereas adults may be sedentary (Ueda et al., 2016; Wilbur, 1980). An interesting example of aquatic organisms that have a complex lifecycle comprises freshwater mussels (Bivalvia, Unionida) (Modesto et al., 2018). They are a diverse animal group distributed worldwide except Antarctica, being highly threatened and suffering major declines over the last century (Lopes-Lima et al., 2014, 2018). The life cycle of freshwater mussels includes a parasitic life stage as larvae (named glochidia), which are released by females and need to attach to fish hosts (rarely attaching to other vertebrates) to continue its development into juvenile mussels (Barnhart et al., 2008; Douda et al., 2013; Lopes-Lima et al., 2016; Modesto et al., 2018). The poor conservation status of freshwater mussels is associated, in part, to their complex and unique life-cycle in addition to the increased of human disturbance on freshwater ecosystems (Lopes-Lima et al., 2017; Santos et al., 2015; Sousa et al., 2014; Strayer et al., 2004).

Probably one of the major drivers of native freshwater mussels' declines is the introduction of invasive alien species (IAS) (Bódis et al., 2014a; Ferreira-Rodríguez et al., 2018; Sousa et al., 2011a, 2014). IAS are considered a serious threat to native freshwater mussels due to direct competition for food and space, introduction of diseases and parasites and being also responsible for abiotic changes that can disrupt the dynamics of native populations (Boltovskoy and Correa, 2014; Sousa et al., 2005, 2014; Strayer et al., 2004). Bivalves, including species such as Corbicula fluminea (Müller, 1774), Dreissena polymorpha (Pallas, 1771), Limnoperna fortunei (Dunker, 1857), Sinanodonta woodiana (I. Lea, 1834), among others, are considered problematic in freshwater ecosystems, since they can occur at remarkably high densities (Balogh et al., 2008; Bódis et al., 2011, 2014b, 2016; Karatayev et al., 2010; Sousa et al., 2008a, 2008d, 2014).

A relevant example is the invasive bivalve Corbicula fluminea (Müller, 1774) that due to its activities (i.e. burrowing and bioturbation, suspension and deposit feeding, high filtration rates; Ilarri and Sousa, 2012), high density and biomass, and opportunistic behaviour (i.e. ability to colonize different environments, high phenotypic plasticity, high tolerance to abiotic fluctuations, shorter-life cycle, rapid growth, earlier sexual maturity, and great fecundity; Ilarri and Sousa, 2012; McMahon, 2002; Sousa et al., 2008a) have successfully colonized new environments and negatively affected native species (Sousa et al., 2008a). On the invaded ecosystems, high densities of $C$. fluminea can be responsible for impacts ranging from the individuals to the ecosystem (Ilarri et al., 2012, 2015; Ilarri and Sousa, 2012; McMahon, 2000; Novais et al., 2016; Phelps, 1994; Sousa et al., 2009, 2014; Zhang et al., 2011). Corbicula fluminea can change the invaded area through its activities which may also impact native freshwater mussel populations (Haag et al., 1993; Ricciardi et al., 1997; Sousa et al., 2009, 2014; Strayer, 1999). Although there are several studies focusing on $C$. fluminea impacts, only a few have evaluated their negative effects on native freshwater mussels (see Ferreira-Rodríguez et al., 2018; Cherry et al., 2005; Cooper et al., 2005). However, must of these negative impacts on native freshwater mussels remain speculative and untested.
Due to this lack of knowledge, it is crucial to study the possible impacts of $C$. fluminea on freshwater mussels in more detail, especially those that can possibly affect glochidia and the recruitment of juveniles, since this can be the most vulnerable phase of their life cycle (Ferreira-Rodríguez et al., 2019). Therefore, the main goal of the present study is to evaluate, through manipulative experiments, the influence of the invasive bivalve $C$. fluminea on the glochidia survival of the native freshwater mussel species Anodonta anatina (Linnaeus, 1758). The freshwater mussel A. anatina has a wide distribution that includes Europe, Asia and North Africa, being considered a generalist species regarding habitat preferences (Froufe et al., 2014; Hinzmann et al., 2013; Lopes-Lima et al., 2017). Given the usual overlap in distribution between $A$. anatina and $C$. fluminea in Europe, the present study aimed at evaluating: (1) the effect of C. fluminea activities (filtration and biodeposition) and (2) the effect of different ammonia concentrations (simulating $C$. fluminea faeces and pseudofaeces production) on the survival of $A$. anatina glochidia. We hypothesized that the increase of filtration and ammonia concentration will negatively affect the survival of $A$. anatina glochidia and this situation will be density and time dependent.

\section{Methods}

\subsection{Organisms collection}

Corbicula fluminea (130 individuals, average \pm SD size of $30 \pm$ $10 \mathrm{~mm})$ specimens were collected in Praia da Lenta $\left(41^{\circ} 57^{\prime} \mathrm{N}, 08^{\circ} 44^{\prime}\right.$ W), a semi-enclosed area in the Minho River located $14 \mathrm{~km}$ upstream the mouth of river, on January 2018 (for a description of the collection site see Sousa et al., 2013). Minho River is a low human-impacted system, although in the last decades has been subjected to several IAS introductions (for a revision see Sousa et al., 2008c). In fact, the invasive species C. fluminea was first described for the Minho River in 1989 (Araujo et al., 1993) and currently it contributes with $>90 \%$ of the benthic estuarine biomass (Sousa et al., 2008f).

Anodonta anatina ( 6 individuals, average \pm SD size of $97 \pm 13 \mathrm{~mm}$ ) specimens were collected in Tua River, upstream of the city of Mirandela $\left(41^{\circ} 30^{\prime} \mathrm{N} ; 7^{\circ} 11^{\prime} \mathrm{W}\right)$, on January 2018 (the end of the reproduction season of the species in the North of Portugal; Hinzmann et al., 2013). Tua River basin is a well-preserved area in which several native freshwater mussel species (A. anatina, Margaritifera margaritifera (Linnaeus, 1758), Potomida littoralis (Cuvier, 1798), Unio delphinus (Spengler, 1793)) occur (Sousa et al., 2012). The invasive bivalve C. fluminea also occurs in the Tua basin (Sousa et al., 2012).

\subsection{Manipulative experiments}

Invasive bivalves and native freshwater mussels were collected and immediately transported to CIIMAR (Interdisciplinary Centre of Marine and Environmental Research, University of Porto) laboratorial facilities. During the two weeks before the beginning of the experiment, organisms were kept in two aquariums with a total volume of $35 \mathrm{~L}$ with flowing, dechlorinated, and aerated distilled water (acclimation period). The photoperiod (12:12 h of a light-dark cycle) and temperature $\left(15^{\circ} \mathrm{C}\right)$ were kept constant. All organisms were fed daily with Chlorella vulgaris.

In the first laboratorial experiment we evaluated the influence of different $C$. fluminea densities on the survival of $A$. anatina glochidia. In the second laboratorial experiment we evaluated the influence of different ammonia concentrations on the survival of $A$. anatina glochidia. The two manipulative experiments were performed in microcosms with $10 \times 10 \times 18 \mathrm{~cm}\left(100 \mathrm{~cm}^{2}\right.$ of area $)$, filled with $500 \mathrm{~mL}$ of distilled water.

\subsubsection{Influence of Corbicula fluminea on the survival of Anodonta anatina glochidia}

In this manipulative experiment four treatments $(n=5$ per treatment) were used: (1) control (without C. fluminea), (2) 1 ind. $100 \mathrm{~cm}^{-2}$ 
(low density of $C$. fluminea), (3) 5 ind. $100 \mathrm{~cm}^{-2}$ (intermediary density of C. fluminea) and (4) 20 ind. $100 \mathrm{~cm}^{-2}$ (high density of $C$. fluminea). This range of $C$. fluminea densities were selected based on values present on Minho River, that usually range from 500 ind. $\mathrm{m}^{-2}$ to 2000 in. $\mathrm{m}^{-2}$ (Sousa et al., 2008b, 2008d).

Corbicula fluminea individuals were placed in aerated microcosms in the laboratory. Three days after the inclusion of $C$. fluminea, samples with $100 \mathrm{~A}$. anatina glochidia were included in each microcosm using a $3 \mathrm{~mL}$ pipette. Glochidia were collected from gravid females by opening their valves, placing a water-filled syringe into the marsupial gill, and promoting the release of glochidia. The evaluation of glochidia viability was checked by their valve's movement when in contact with a $\mathrm{NaCl}$ solution. Samples of one hundred glochidia were separated to different $20 \mathrm{~mL}$ recipients and then transferred to the microcosms. Thereafter, samples were collected at different time periods: $6 \mathrm{~h}$ (T1), $12 \mathrm{~h}$ (T2), $24 \mathrm{~h} \mathrm{(T3)} \mathrm{and} 48 \mathrm{~h}$ (T4). Along the different time periods, each sample was filtered with a $120 \mu \mathrm{m}$ mesh sieve. Afterward, with the use of a needle, the live and dead glochidia present in each sample were counted. Glochidia with movement were considered as being alive. On contrary, if the valves of the glochidia were broken or without movement they were counted as dead. Total ammonia concentration (considering $97.5 \% \mathrm{NH}_{4}^{+}+2.5 \% \mathrm{NH}_{3}$ ) in the water in each microcosm and time period was assessed using the Auto-analyzer Colorimetric Skalar SanPlus Flow Segmented, Skalar M155-008R (EPA 350.1) method.

\subsubsection{Influence of ammonia on the survival of Anodonta anatina glochidia}

The same experimental design was used to evaluate the possible influence of ammonia on the survival of $A$. anatina glochidia. A total of nine treatments and eight different concentrations of total ammonia (considering 97.5\% $\mathrm{NH}_{4}^{+}+2.5 \% \mathrm{NH}_{3}$ ) were tested: (1) control, (2) $0.05 \mathrm{mg} \cdot \mathrm{L}^{-1}$, (3) $0.10 \mathrm{mg} \cdot \mathrm{L}^{-1}$, (4) $0.25 \mathrm{mg} \cdot \mathrm{L}^{-1}$, (5) $0.5 \mathrm{mg} \cdot \mathrm{L}^{-1}$, (6) $1 \mathrm{mg} \cdot \mathrm{L}^{-1}$, (7) $2.5 \mathrm{mg} \cdot \mathrm{L}^{-1}$, (8) $5 \mathrm{mg} \cdot \mathrm{L}^{-1}$, (9) $10 \mathrm{mg} \cdot \mathrm{L}^{-1}$. The lowest five concentrations were selected to mimic the concentrations of ammonia measured during the first experiment (see above). The other four concentrations were selected taking into account the amount of ammonia in water that is considered to be toxic in Portuguese ecosystems (Ministério do Ambiente, 1998). During the experiment pH and temperature were measured using a multi-parameter analyzer Consort C562 since ammonia concentrations may be affected by these abiotic factors (see Wang et al., 2008). As in the previous experiment (see above), live and dead glochidia were counted at the same time periods T1, T2, T3 and T4 as described above.

\subsection{Data analysis}

To evaluate the possible influence of $C$. fluminea density and ammonia concentration on survival of $A$. anatina glochidia over time (first laboratorial experiment), a Generalized Linear Model (GLM) was fitted to the data. Mortality of $A$. anatina glochidia in the different densities of C. fluminea and time were modelled using a negative binomial (NB) distribution (following Zuur et al., 2009), given that the preliminary analysis showed that the data had over-dispersion (i.e. the variance of the data were much higher than the average). The model included a response variable: mortality of $A$. anatina glochidia, and two predictor continuous variables: $C$. fluminea density and time. In addition, given that ammonia excretion by $C$. fluminea accumulates over time and depends on density, this variable was included into the model as a continuous covariate. The residuals of the model were checked regarding the assumptions of normal and homogeneous error, and for the goodness of fit it was assessed with the Hosmer-Lemeshow Goodness of Fit (GOF) test from the package ResourceSelection (Lele, 2009). The statistical significance of variance used were of $\alpha=0.05$. The data was modelled with the glm.nb function from the package MASS (Venables and Ripley, 2002) implemented in R (R Core Team, 2014).

To assess the possible influence of ammonia on the survival of A. anatina glochidia over time (second laboratorial experiment), a two-way PERMANOVA (type III) was used. The mortality of A. anatina glochidia over time was tested with a two-way PERMANOVA (typeIII), with ammonia (nine levels: [control], [0.05], [0.10], [0.25], [0.50], [1], [2.5], [5], [10]) and time (four levels: T1, T2, T3 and T4) as fixed factors. Prior to the analyses, data were fourth root transformed and a resemblance matrix based on the Euclidean distance was calculated. For the PERMANOVA tests the statistical significance of variance $(\alpha=$ 0.05) was tested considering 9999 permutations of residuals within a reduced model. If the number of permutations were lower than 150 , the Monte Carlo $p$-value was considered. Pairwise comparisons were performed for all PERMANOVA tests. PRIMER software (version 6.0 with the PERMANOVA + add-on package; Clarke and Gorley, 2006; Anderson et al., 2008) was used for the PERMANOVA tests.

\section{Results}

3.1. Influence of Corbicula fluminea on the survival of Anodonta anatina glochidia

The mortality of $A$. anatina glochidia increased with higher densities of $C$. fluminea and over time (Fig. 1). Mortality varied between 3.4 ( \pm $1.82)$ in control during $\mathrm{T} 1$ and $53.0( \pm 4.06)$ in the treatment with 20 ind. $100 \mathrm{~cm}^{-2}$ during T4.

Ammonia concentration increased with higher densities of C. fluminea and over time (Fig. 2). Ammonia varied between 0.02 ( \pm $0.006) \mathrm{mg} \cdot \mathrm{L}^{-1}$ in control during $\mathrm{T} 1$ and $1.45( \pm 0.970) \mathrm{mg} \cdot \mathrm{L}^{-1}$ in the treatment with 20 ind. $100 \mathrm{~cm}^{-2}$ during T3.

Mortality of $A$. anatina glochidia positively responds to the variables ammonia, density of $C$. fluminea and time, the GLM indicated a positive significant correlation of $A$. anatina glochidia mortality with these variables (Table 1). The GLM had a predictive capacity of $\mathrm{r}^{2}=0.57$.

\subsection{Influence of ammonia on the survival of Anodonta anatina glochidia}

Mortality of A. anatina glochidia increased with higher ammonia concentrations and over time. Mortality varied between $1.0( \pm 1.73)$ in control during T1 and $66.2( \pm 6.38)$ in the treatment with $10 \mathrm{mg} \cdot \mathrm{L}^{-1}$ during T4 (Fig. 3).

Mortality of $A$. anatina glochidia varied significantly in response to ammonia concentration and time (Table 2). Regarding ammonia concentrations, the pairwise tests showed that the mortality varied between the lower (from 0.05 to $0.5 \mathrm{mg} \cdot \mathrm{L}^{-1}$ ) and higher (from 1 to $10 \mathrm{mg} \cdot \mathrm{L}^{-1}$ ) ammonia concentrations (Fig. 3 ). For time, the differences on pairwise tests were between all times of the experiment with exception of T2 with T3 (Fig. 3).

Mortality of A. anatina glochidia was recorded for all ammonia concentrations (Fig. 3). However, a mortality of $50 \%$ of A. anatina glochidia

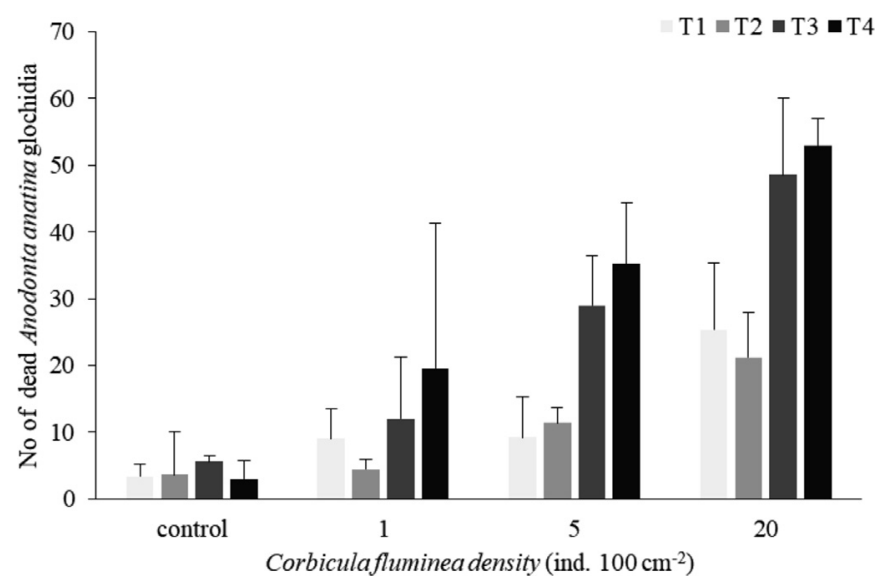

Fig. 1. Average $(+\mathrm{SD})$ values of dead Anodonta anatina glochidia in four different densities of Corbicula fluminea and over time. 


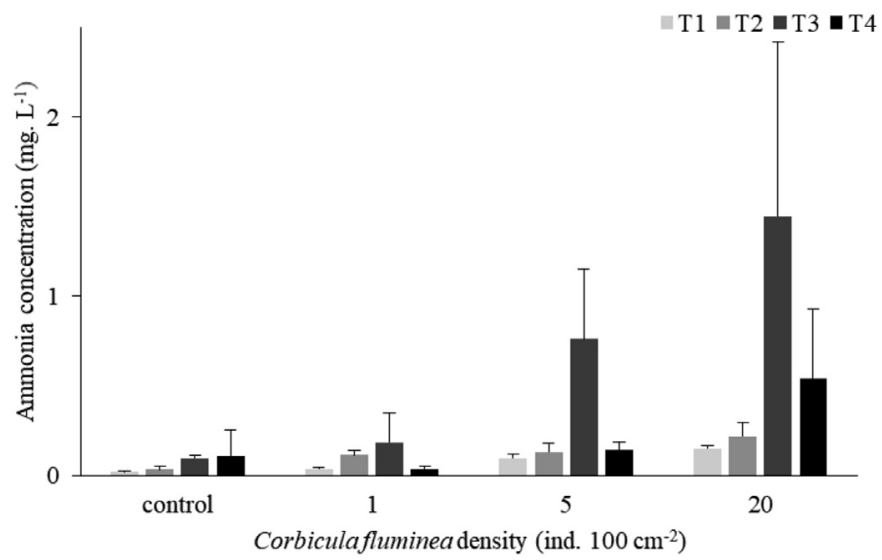

Fig. 2. Average $(+S D)$ values of ammonia concentration in four different densities of Corbicula fluminea and over time.

was only observed for the ammonia concentration of $10 \mathrm{mg} \cdot \mathrm{L}^{-1}$ and only after $48 \mathrm{~h}$ (T4) (Table 3 ).

\section{Discussion}

High mortality rates during the glochidia and juvenile stages, due to failures in attachment to appropriate fish hosts and settlement in unsuitable habitats, are well known in freshwater mussel species (Cherry et al., 2005; Modesto et al., 2018; Neves and Widlak, 1987). Indeed, the number of glochidia produced by a female freshwater mussel can reach $>10,000,000$; however, most species have very low survival rates of glochidia with $99.99 \%$ failing to attach to a suitable host and therefore not completing their development into juveniles (Bauer, 1987; Haag, 2012, 2013; Jansen et al., 2001; Modesto et al., 2018; Strayer, 2008; Young and Williams, 1984). As such, information regarding the survival of freshwater mussels during this early stage of their life-cycle is crucial to the conservation of these species (FerreiraRodríguez et al., 2019). The present study showed that $C$. fluminea can negatively affect the survival of $A$. anatina glochidia, with possible repercussions in their recruitment and future conservation, and shed light about the main mechanisms responsible for this mortality. Similar results (or even more critical) are expected for other freshwater mussel species (see further discussion below).

IAS can strongly affect the abundance of native mussels (Strayer, 1999). In this regard, the effects of some well-known invasive species (Dreissena polymorpha and Limnoperna fortunei) have been well documented (Carlsson et al., 2009; Clayton et al., 2001; Karatayev et al., 2007; Kat, 1986; Mansur et al., 2012; Ricciardi et al., 1998; Sousa et al., 2011b). In contrast, for the Asian clam C. fluminea, and despite the numerous studies suggesting their negative effects on native freshwater mussels, few included quantitative evidences of these impacts (Cherry et al., 2005; Cooper et al., 2005; Ferreira-Rodríguez et al., 2018; Neves and Cherry, 1999; Scheller, 1997). Not to mention that in most cases these studies have focused in the impacts on young juveniles

Table 1

Generalized linear model outputs of the model fitted to quantify the variation of dead Anodonta anatina glochidia throughout different densities of Corbicula fluminea and ammonia concentration over time (negative binomial model).

\begin{tabular}{lllll}
\hline & Estimate & SE & z-value & $p$ value \\
\hline Intercept & 1.21 & 0.21 & 5.78 & $<0.05$ \\
Ammonia & 3.89 & 1.36 & 2.87 & $<0.05$ \\
Density & 0.07 & 0.02 & 4.14 & $<0.05$ \\
Time & 0.03 & 0.01 & 4.57 & $<0.05$ \\
Ammonia:Density & -0.09 & 0.07 & -1.36 & 0.17 \\
Ammonia:Time & -0.05 & 0.04 & -1.21 & 0.22 \\
\hline
\end{tabular}

Italics refer to significant $p$ value. (immediately following metamorphosis) or adults (Cherry et al., 2005; Cooper et al., 2005; Ferreira-Rodríguez et al., 2018; Neves and Cherry, 1999; Scheller, 1997). For example, in a recent study, FerreiraRodríguez et al. (2018) reported lower growth and physiological condition, and higher locomotor activity in U. delphinus adults in the presence of higher $C$. fluminea densities. Other studies described that massive mortalities of $C$. fluminea are also associated to the mortality of Villosa iris (Lea, 1829) and Pyganodon grandis (Say, 1829), both adults and juveniles, due to increased ammonia toxicity during the decomposition process (Cherry et al., 2005; Cooper et al., 2005). As far as we know, Neves and Cherry (1999) is the only study that have demonstrated a negative correlation between glochidia abundance (using $V$. iris) and the presence of $C$. fluminea. The authors concluded that this negative correlation was probably a result of $C$. fluminea ingestion of glochidia during filtration and consequent release of these glochidia on their faeces and/or pseudofaeces.

The Asian clam C. fluminea has a high filtration capacity (it can range from 29 to $3252 \mathrm{ml} . \mathrm{h}^{-1}$. ind ${ }^{-1}$ ) compared to other bivalves (Boltovskoy et al., 1995; Cohen et al., 1984; Viergutz et al., 2012; Vohmann et al., 2010). Since C. fluminea can attain remarkable densities on the invaded ecosystems (Cataldo and Boltovskoy, 1999; Cohen et al., 1984; Modesto et al., 2013; Phelps, 1994; Sousa et al., 2008e) this filtration capacity can remove food resources or impair the reproduction and/or recruitment of native freshwater mussels. In fact, $C$. fluminea has been cited as an important threat to reproduction or recruitment of native freshwater mussels, either by removing sperm or in a latter phase being responsible for the mortality of glochidia and/or newly metamorphosed juveniles (Sousa et al., 2014; Strayer, 1999). In addition, the increase of toxic ammonia as a result of great quantities of faeces and pseudofaeces production or during massive mortalities has been also described as an important possible mechanism of threat to freshwater mussels (Scheller, 1997; Sousa et al., 2014; Strayer, 1999; Neves and Cherry, 1999).

In the present study, the activities of $C$. fluminea (filtration and biodeposition) probably contributed to the mortality of A. anatina glochidia. This was especially valid for the treatments with densities higher than 20 ind. $100 \mathrm{~cm}^{-2}$ (2000 ind. $\mathrm{m}^{-2}$ ), and that were in contact with $C$. fluminea for $>48 \mathrm{~h}$. Since $C$. fluminea filter suspended particles across the gill (McMahon, 1991), when the food and non-food particles enter via the incurrent siphon, the gill works as a sieve concentrating the smaller (in the range of 15-25 $\mu \mathrm{m}$ ) particles (Atkinson et al., 2011; Bayne and Newell, 1983; Decho and Luoma, 1991). Once inside the gills, particles can follow two different pathways. Food particles can move across from the anterior end of the gills to the labial palps, then the anterior food grove to the esophagus and finally to the stomach and gut (Cummings and Bogan, 2006). When these particles are big, they might be fragmented in smaller fractions due to the complex digestive system of C. fluminea (Decho and Luoma, 1991; McMahon, 1991). In fact, these clams have a highly efficient digestive system, which allows them to return undigested particles from the stomach to the gut several times for further assimilation (Decho and Luoma, 1991; McMahon, 1991). Finally, these particles can be excreted as faeces that are released involved on mucous secreted by the gut and rectal cells through the excurrent siphon (Decho and Luoma, 1991; McMahon, 1991; Cummings and Bogan, 2006). On the other hand, non-food particles can be sorted, moving off the ventral margin of the gills, and can be released through the incurrent siphon or mantle bounded by the mucous formed along the pedal gape as pseudofaeces (Cummings and Bogan, 2006; Decho and Luoma, 1991; McMahon, 1991). Therefore, considering that the size of $A$. anatina larvae is much higher than the particles filtered by C. fluminea (in Portuguese populations the size of $A$. anatina glochidia may vary between 340 and $566 \mu \mathrm{m}$; Lopes-Lima et al., 2016), these glochidia when filtered and ingested might be fragmented in small pieces. These glochidia are probably not assimilated by $C$. fluminea, and consequently are returned from the stomach to the gut several times being fragmented, killed and excreted as faeces, or even 


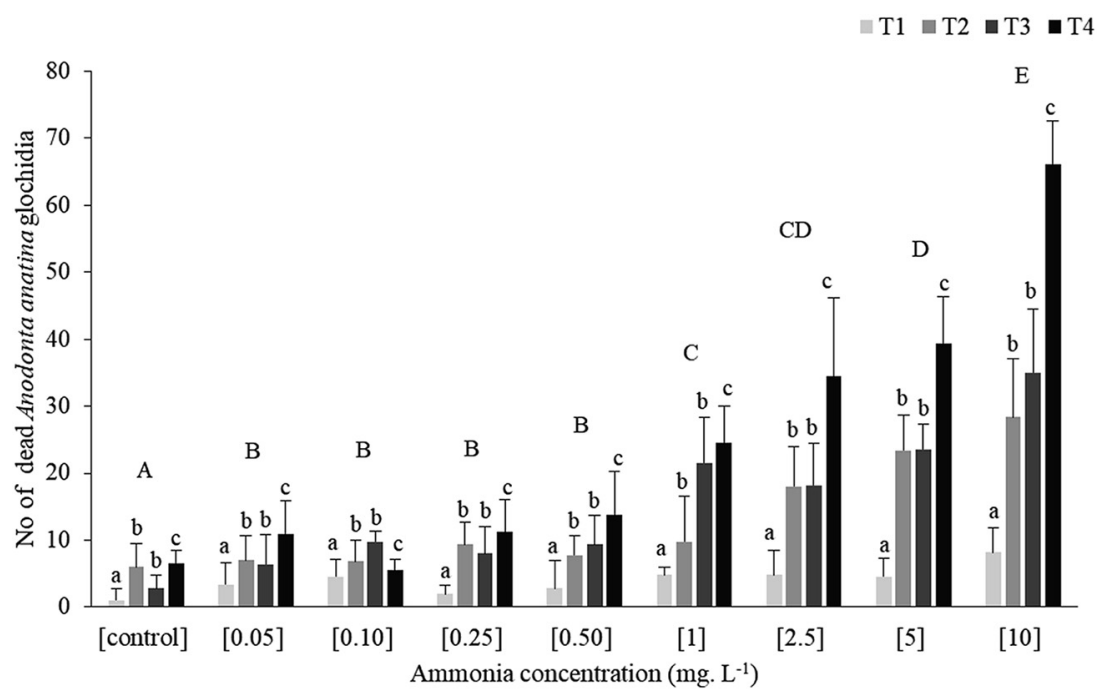

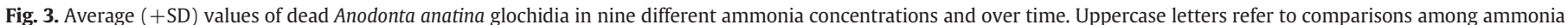
concentrations, while lowercase letters to comparisons among time periods.

entangled in the mucous as pseudofaeces (Neves and Cherry, 1999). In the present study most of the dead glochidia observed in the first experiment were found in these conditions (i.e., broken in small fragments and entangled in mucous), with the higher density of $C$. fluminea and longer exposures contributing to an increasing mortality.

Although this experiment was just focused on the A. anatina glochidia it is possible that similar results would be obtained with other freshwater mussel species. In fact, the size of glochidia in other species are usually smaller (range between 70 and $385 \mu \mathrm{m}$; Araujo et al., 2009; Bauer, 2001; Kennedy and Haag, 2005) and theoretically more sensitive than described for A. anatina in this study. Therefore, future studies should conduct similar experiments in order to assess the impacts of $C$. fluminea on glochidia survival of other freshwater mussel species that live in sympatry with this IAS.

In the present study it was also possible to observe that faeces and pseudofaeces of $C$. fluminea do not seem to produce levels of ammonia (between 0 and $0.5 \mathrm{mg} \cdot \mathrm{L}^{-1}$ ) high enough to strongly affect the A. anatina glochidia; however, some mortality was directly related to the ammonia levels. The ammonia measured in the study was the total ammonia, including the unionized $\left(\mathrm{NH}_{3}\right)$ and the ionized $\left(\mathrm{NH}_{4}^{+}\right)$ ammonia. Although $\mathrm{NH}_{3}$ is very toxic to aquatic organisms (Erickson et al., 2008; Redner and Stickney, 1979), including the glochidia of freshwater mussels (Augspurger et al., 2003; Wang et al., 2007a), A. anatina glochidia showed a high tolerance to ammonia toxicity in the second experiment, since the $\mathrm{EC}_{50}$ was only reached at $10 \mathrm{mg} \cdot \mathrm{L}^{-1}$ of total ammonia after $48 \mathrm{~h}$ (Table 3). Ingersoll et al. (2006) reported that many species belonging to the subfamily Anodontinae have highly resilient glochidia, since after being discharge by females, they remain viable for days in the water before attachment to the fish hosts. This resilience varies between different freshwater mussel subfamilies, being usually higher in the subfamily Anodontinae (Table 3). Wang et al. (2007b) described a lower toxicity resistance by Venustaconcha

Table 2

Summary of two-way PERMANOVA results comparing the number of dead Anodonta anatina glochidia in different ammonia concentrations and over time.

\begin{tabular}{llllll}
\hline Source & df & SS & MS & Pseudo-F & P \\
\hline Ammonia & 8 & 20.34 & 2.54 & 26.49 & $<0.05$ \\
Time & 3 & 18.19 & 6.06 & 63.18 & $<0.05$ \\
Ammonia $\times$ Time & 24 & 3.62 & 0.15 & 1.57 & 0.05 \\
\hline
\end{tabular}

Italics refer to significant $p$ value. ellipsiformis of the subfamily Ambleminae, wherein the $\mathrm{EC}_{50}$ of glochidia tested was $2.7 \mathrm{mg} \cdot \mathrm{L}^{-1}$ of total ammonia concentration after $48 \mathrm{~h}$.

With the increasing distribution of the C. fluminea worldwide (Crespo et al., 2015), and the high densities that this species can attain, the possibility that this IAS dominate the benthic biomass and negatively affect the native freshwater mussel species is high. The results reported here strongly suggest that the invasive bivalve $C$. fluminea can negatively influence the recruitment of the native freshwater mussel A. anatina causing the mortality of their glochidia. Thus, invasion of C. fluminea is a plausible, but possibly overlooked, explanation for some of the declines in freshwater mussels registered in the last decades (Haag, 2012). Evidences that $C$. fluminea has strong and pervasive negative effects in freshwater mussels is still debatable. In fact, some authors described that $C$. fluminea and the native freshwater mussels occupy different microhabitats, with $C$. fluminea occurring in high densities in areas that the freshwater mussels occur in low densities (Vaughn and Spooner, 2006). This non-overlapping distribution may indicate (among other hypotheses) that freshwater mussels are not able to persist in high density areas of $C$. fluminea. In addition to possible competition for food and habitat, our study showed that $C$. fluminea can increase the mortality of glochidia, and this could lead to possible negative effects on the recruitment of freshwater mussels.

\section{Conclusions}

Corbicula fluminea is recognized as one of the most problematic IAS in freshwater ecosystems and is usually described as a possible threat to the conservation of native freshwater mussels. Despite of this, to date very few studies were able to provide quantitative evidences of this situation. Results of the present study showed that the mortality of the native freshwater $A$. anatina glochidia increased with higher densities of $C$. fluminea and when submitted to long time periods in contact with this IAS. Filtration and consequent ingestion of glochidia and biodeposition activities were the main possible mechanisms responsible for the high mortalities registered. It was also possible to observe that $C$. fluminea do not seem to produce levels of ammonia high enough to strongly affect $A$. anatina glochidia. Though, more manipulative experiments are necessary to better understand and to compare the effects of the invasive $C$. fluminea in other freshwater mussel species that are highly threatened and live in sympatry with this IAS. 
Table 3

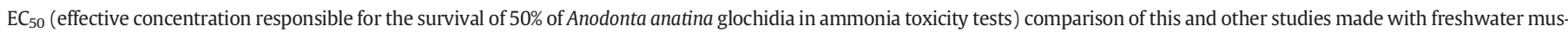
sel species during a $48 \mathrm{~h}$ period.

\begin{tabular}{|c|c|c|c|}
\hline \multirow[t]{2}{*}{ Species } & \multirow[t]{2}{*}{ Subfamilies } & Total ammonia $\mathrm{EC}_{50}\left(\mathrm{mg} \mathrm{N} \cdot \mathrm{L}^{-1}\right)$ & \multirow[t]{2}{*}{ References } \\
\hline & & $48 \mathrm{~h}$ & \\
\hline Anodonta anatina & Anodontinae & 10.0 & Present study \\
\hline Actinonaias ligamentina & Ambleminae & $3.3-8.0$ & \\
\hline Lampsilis siliquoidea & Ambleminae & $7.7-13.0$ & Wang et al., 2007a \\
\hline Actinonaias ligamentina & Ambleminae & $3.3-8.0$ & \\
\hline Alasmidonta heterodon & Anodontinae & $15.0-16.0$ & \\
\hline Lampsilis fasciola & Ambleminae & $4.0-6.7$ & \\
\hline Lampsilis siliquoidea & Ambleminae & $7.7-13.0$ & \\
\hline Lampsilis rafinesqueana & Ambleminae & $5.5-6.0$ & \\
\hline Venustaconcha ellipsiformis & Ambleminae & $2.5-2.9$ & \\
\hline Villosa iris & Ambleminae & $8.8-9.6$ & Wang et al., 2007b \\
\hline
\end{tabular}

\section{Acknowledgments}

VM, MLL and PC were supported by doctoral grants (SFRH/BD/ 108298/2015), (SFRH/BD/115728/2016) and (SFRH/BD/131814/2017) from the Portuguese Foundation for Science and Technology - FCT through POPH/FSE funds. This study was conducted within the project FRESHCO - Multiple implications of invasive species on Freshwater Mussel coextinction processes, supported by FCT and COMPETE funds (contract: PTDC/AGRFOR/1627/2014). This study was also supported by the FCT project UID/Multi/04423/2019. We thank Allan Souza, Francisco Arenas, Jacinto Cunha and Lúcia Guilhermino for their help in the design of the experiment. We also thank the editor and three anonymous referees for valuable suggestions.

\section{References}

Allen, R.M., Metaxas, A., Snelgrove, P.V.R., 2018. Applying movement ecology to marine animals with complex life cycles. Annu. Rev. Mar. Sci. 10, 19-42.

Anderson, M.J., Gorley, R.N., Clarke, K.R., 2008. PERMANOVA+ for PRIMER: Guide to Software and Statistical Methods. PRIMER-E, Plymouth.

Araujo, R., Moreno, D., Ramos, M.A., 1993. The Asiatic clam Corbicula fluminea (Müller, 1774) (Bivalvia: Corbiculidae) in Europe. Amer. Malac. Bull. 10, 39-49.

Araujo, R., Toledo, C., Machordom, A., 2009. Redescription of Unio gibbus Spengler, 1793, a west palaearctic freshwater mussel with hookless glochidia. Malacologia 51, 131-141.

Atkinson, C.L., First, M.R., Covich, A.P., Opsahl, S.P., Golladay, S.W., 2011. Suspended material availability and filtration-biodeposition processes performed by a native and invasive bivalve species in streams. Hydrobiologia 667, 191-204.

Augspurger, T., Keller, A.E., Black, M.C., Cope, W.G., Dwyer, F.J., 2003. Water quality guidance for protection of freshwater mussels (Unionidae) from ammonia exposure. Environ. Toxicol. Chem. 22 (11), 2569-2575.

Balogh, C., Muskó, I.B., László, G., Nagy, L., 2008. Quantitative trends of zebra mussels in Lake Balaton (Hungary) in 2003-2005 at different water levels. Hydrobiologia 613 (1), 57-69.

Barnhart, M.C., Haag, W.R., Roston, W.N., 2008. Adaptations to host infection and larval parasitism in Unionoida. J. North Am. Benthol. Soc. 27, 370-394.

Bauer, G., 1987. The parasitic stage of the freshwater pearl mussel (Margaritifera margaritifera L.) III. Host relationships. Arch. Hydrobiol. 76, 413-423.

Bauer, G., 2001. Life-history variation on different taxonomic levels of naiads. Ecology and Evolution of the Freshwater Mussels Unionoida. Springer, Berlin, Heidelberg, pp. 83-91.

Bayne, B.L., Newell, R.C., 1983. Physiological energetics of marine molluscs. The Mollusca 4, 407-515.

Bódis, E., Nosek, J., Oertel, N., Tóth, B., Hornung, E., Sousa, R., 2011. Spatial distribution of bivalves in relation to environmental conditions (middle Danube catchment, Hungary). Community Ecol. 12, 210-219.

Bódis, E., Tóth, B., Sousa, R., 2014a. Impact of Dreissena fouling on the physiological condition of native and invasive bivalves: interspecific and temporal variations. Biol. Invasions 16, 1373-1386.

Bódis, E., Tóth, B., Sousa, R., 2014b. Massive mortality of invasive bivalves as a potential resource subsidy for the adjacent terrestrial food web. Hydrobiologia 735, 253-262.

Bódis, E., Tóth, B., Sousa, R., 2016. Freshwater mollusc assemblages and habitat associations in the Danube River drainage, Hungary. Aquat. Conserv. Mar. Freshwat. Ecosyst. 26 (319-332), 2585.

Boltovskoy, D., Correa, N., 2014. Ecosystem impacts of the invasive bivalve Limnoperna fortunei (golden mussel) in South America. Hydrobiologia 746, 81-95.

Boltovskoy, D., Izaguirre, I., Correa, N., 1995. Feeding selectivity of Corbicula fluminea (Bivalvia) on natural phytoplankton. Hydrobiologia 312, 171-182.

Carlsson, N.O.L., Sarnelle, O., Strayer, D.L., 2009. Native predators and exotic prey - an acquired taste? Front. Ecol. Environ. 7, 525-532.
Cataldo, D., Boltovskoy, D., 1999. Population dynamics of Corbicula fluminea (Bivalvia) in the Paraná River Delta (Argentina). Hydrobiologia 380, 153-163.

Cherry, D.S., Scheller, J.L., Cooper, N.L., Bidwell, J.R., 2005. Potential effects of Asian clam (Corbicula fluminea) dieoffs on native freshwater mussels (Unionidae) I: water column ammonia levels and ammonia toxicity. J. North Am. Benthol. Soc. 24, 369-380.

Clarke, K.R., Gorley, R.N., 2006. PRIMER v6: User Manual/Tutorial. PRIMER-E, Plymouth, p. 192.

Clayton, J.L., Stihler, C.W., Wallace, J.L., 2001. Status and potential impacts to the freshwater bivalves (Unionidae) in Patterson Creek, West Virginia. Northeast. Nat. 8, 179-188.

Cohen, R.R.H., Dresler, P.V., Phillips, E.J.P., Cory, R.L., Phillips, J.P., Cory, L., 1984. The effect of the Asiatic clam, Corbicula fluminea, phytoplankton of the Potomac River, Maryland. Limnol. Oceanogr. 29, 170-180.

Combes, C., 1997. Fitness of parasites: pathology and selection. Int. J. Parasitol. Parasites Wildl. 27, 1-10.

Cooper, N.L., Bidwell, J.R., Cherry, D.S., 2005. Potential effects of Asian clam (Corbicula fluminea) die-offs on native freshwater mussels (Unionidae) II: pore-water ammonia. J. North Am. Benthol. Soc. 24, 381-394.

Crespo, D., Dolbeth, M., Leston, S., Sousa, R., Pardal, M.Â., 2015. Distribution of Corbicula fluminea (Müller, 1774) in the invaded range: a geographic approach with notes on species traits variability. Biol. Invasions 17, 2087-2101.

Cummings, K.S., Bogan, A.E., 2006. Unionoida: Freshwater Mussels. The Mollusks: A Guide to their Study, Collection, and Preservation. American Malacological Society, Pittsburgh, pp. 313-326.

Decho, A., Luoma, S., 1991. Time-courses in the Retention of Food Material in the Bivalves 78. S Geol. Surv, MS 465,345 Middlef. Rd., Menlo Park. Calif. 94025, USA pp. 303-314.

Douda, K., Lopes-Lima, M., Hinzmann, M., Machado, J., Varandas, S., Teixeira, A., Sousa, R. 2013. Biotic homogenization as a threat to native affiliate species: fish introductions dilute freshwater mussel's host resources. Divers. Distrib. 19, 933-942.

Erickson, R.J., Nichols, J.W., Cook, P.M., Ankley, G.T., 2008. Bioavailability of chemical contaminants in aquatic systems. In: DiGiulio, R.T., Hinton, D.E. (Eds.), The Toxicology of Fishes. CRC Press, Boca Raton, FL, USA, pp. 9-54.

Ferreira-Rodríguez, N., Sousa, R., Pardo, I., 2018. Negative effects of Corbicula fluminea over native freshwater mussels. Hydrobiologia 810, 85-95.

Ferreira-Rodríguez, N., Akiyama, B.Y., Aksenova, O., Araujo, R., Barnhart, C., Bespalaya, Y Bogan, A., Bolotov, I.N., Budha, P.B., Clavijo, C., Clearwater, S.J., Darrigran, G., Do, V.T., Douda, K., Froufe, E., Graf, D., Gumpinger, C., Humphrey, C.L., Johnson, N.A., Klishko, O., Klunzinger, M.W., Kovitvadhi, S., Kovitvadhi, U., Lajtner, J., Lennart, H., LopesLima, M., Moorkens, E.A., Nagayama, S., Nagel, K.-O., Nakano, M., Negishi, J., Ondina, P., Oulasvirta, P., Pfeiffer, P., Prié, V., Riccardi, N., Rudzīte, M., Seddon, M., Sheldon, F., Sousa, R., Strayer, D.L., Takeuchi, M., Taskinen, J., Teixeira, A., Tiemann, J., Urbańska, M., Varandas, S., Vinarski, M., Wicklow, B.J., Zając, T., Vaughn, C.C., 2019. Research priorities for freshwater mussel conservation assessment. Biol. Conserv. 231, 77-87.

Froufe, E., Sobral, C., Teixeira, A., Sousa, R., Varandas, S., Aldridge, D.C., Lopes-Lima, M. 2014. Genetic diversity of the pan-European freshwater mussel Anodonta anatina (Bivalvia: Unionoida) based on CO1: new phylogenetic insights and implications for conservation. Aquat. Conserv. Mar. Freshwat. Ecosyst. 24, 561-574.

Galetti, M., Moleón, M., Jordano, P., Pires, M.M., Guimarães, P.R., Pape, T., Nichols, E. Hansen, D., Olesen, J.M., Munk, M., de Mattos, J.S., Schweiger, A.H., Owen-Smith, N., Johnson, C.N., Marquis, R.J., Svenning, J.C., 2018. Ecological and evolutionary legacy of megafauna extinctions. Biol. Rev. 93, 845-862.

Haag, W.R., 2012. North American Freshwater Mussels: Natural History, Ecology, and Conservation. Cambridge University Press.

Haag, W.R., 2013. The role of fecundity and reproductive effort in defining life-history strategies of North American freshwater mussels. Biol. Rev. 88, 745-766.

Haag, W.R., Berg. D.J., Garton, D.W., Farris, J.L., 1993. Reduced survival and fitness in native bivalves in response to fouling by the introduced zebra mussel (Dreissena polymorpha) in western Lake Erie. Can. J. Fish. Aquat. Sci. 50, 13-19.

Hadfield, M.G., 2000. Why and how marine-invertebrate larvae metamorphose so fast Semin. Cell Dev. Biol. 11, 437-443.

Hinzmann, M., Lopes-Lima, M., Teixeira, A., Varandas, S., Sousa, R., Lopes, A., Froufe, E., Machado, J., 2013. Reproductive cycle and strategy of Anodonta anatina (L., 1758): notes on hermaphroditism. J. Exp. Zool. Part A Ecol. Genet. Physiol. 319, 378-390. 
Hyeun-Ji, L., Johansson, F., 2015. Compensating for a bad start: compensatory growth across life stages in an organism with a complex life cycle. Can. J. Zool. 94 (1), 41-47.

Ilarri, M., Sousa, R., 2012. Corbicula fluminea Müller (Asian clam). In: Francis, R.A. (Ed.), A Handbook of Global Freshwater Invasive Species. Earthscan, London, pp. 173-183.

Ilarri, M.I., Freitas, F., Costa-dias, S., Antunes, C., Guilhermino, L., Sousa, R., 2012. Associated macrozoobenthos with the invasive Asian clam Corbicula fluminea. J. Sea Res. 72, $113-120$.

Ilarri, M.I., Souza, A.T., Sousa, R., 2015. Contrasting decay rates of freshwater bivalves' shells: aquatic versus terrestrial habitats. Limnologica 51, 8-14.

Ingersoll, C.G., Kernaghan, N.J., Gross, T.S., Bishop, C.D., Wang, N., Roberts, A., 2006. Laboratory toxicity testing with freshwater mussels. In: Farris, J.L., van Hassel, J.H. (Eds.) Freshwater Bivalve Ecotoxicology. SETAC, Pensacola, FL, USA, pp. 95-134.

Jansen, W., Bauer, G., Meike, E.Z., 2001. Glochidial mortality in freshwater mussels. In: Bauer, G., Wachtler, K. (Eds.), Ecology and Evolution of the Freshwater Mussels Unionoida. Springer, Berlin, pp. 185-210.

Karatayev, A.Y., Boltovskoy, D., Padilla, D.K., Burlakova, L.E., 2007. The invasive bivalves Dreissena polymorpha and Limnoperna fortunei: parallels, contrasts, potential spread and invasion impacts. J. Shellfish Res. 26, 205-213.

Karatayev, A.Y., Burlakova, L.E., Karatayev, V.A., Boltovskoy, D., 2010. Limnoperna fortunei versus Dreissena polymorpha: population densities and benthic community impacts of two invasive freshwater bivalves. J. Shellfish Res. 29, 975-984.

Kat, P.W., 1986. Hybridization in a unionid faunal suture zone. Malacologia 27, $107-126$

Kennedy, T.B., Haag, W.R., 2005. Using morphometrics to identify glochidia from a diverse freshwater mussel community. J. North Am. Benthol. Soc. 24, 880-889.

Lele, S.R., 2009. A new method for estimation of resource selection probability function. J. Wildl. Manag. 73, 122-127.

Lopes-Lima, M., Teixeira, A., Froufe, E., Lopes, A., Varandas, S., Sousa, R., 2014. Biology and conservation of freshwater bivalves: past, present and future perspectives. Hydrobiologia 735 (1), 1-13.

Lopes-Lima, M., Hinzmann, M., Teixeira, A., Varandas, S., Machado, J., Sousa, R., Froufe, E. 2016. The strange case of the tetragenous Anodonta anatina. J. Exp. Zool. Part A Ecol. Genet. Physiol. 325, 52-56.

Lopes-Lima, M., Sousa, R., Geist, J., Aldridge, D.C., Araujo, R., Bergengren, J., Bespalaya, Y., Bódis, E., Burlakova, L., Van Damme, D., Douda, K., Froufe, E., Georgiev, D., Gumpinge C. Karatayev, A., Kebapçi, Ü., Killeen, I., Lajtner, J., Larsen, B.M., Lauceri, R., Legakis, A Lois, S., Lundberg, S., Moorkens, E., Motte, G., Nagel, K.O., Ondina, P., Outeiro, A., Paunovic, M., Prié, V., von Proschwitz, T., Riccardi, N., Rudzīte, M., Rudzītis, M., Scheder, C., Seddon, M., Sereflişan, H., Simić, V., Sokolova, S., Stoeckl, K., Taskinen, J. Teixeira, A., Thielen, F., Trichkova, T., Varandas, S., Vicentini, H., Zajac, K., Zajac, T. Zogaris, S., 2017. Conservation status of freshwater mussels in Europe: state of the art and future challenges. Biol. Rev. 92, 572-607.

Lopes-Lima, M., Burlakova, LE, Karatayev, A.Y, Mehler, K, Seddon, M, Sousa, R, 2018 Conservation of freshwater bivalves at the global scale: diversity, threats and research needs. Hydrobiologia 810, 1-14.

Mansur, M., dos Santos, C., Pereira, D., Paz, I., Zurita, M., Rodriguez, M., Nehrke, M. Bergonci, P., 2012. Moluscos límnicos invasores no Brasil: biologia, prevencão, controle. Redes Editora, Porto Alegre.

McMahon, R.F., 1991. Mollusca: Bivalvia. In: Thorp, J.H., Covich, A.P. (Eds.), Ecology and Classification of North American Freshwater Invertebrates. Academic Press, New York, pp. 315-399.

McMahon, R.F., 2000. Invasive characteristics of the freshwater bivalve Corbicula fluminea. In: Claudi, R., Leach, J. (Eds.), Nonindigenous Freshwater Organisms: Vectors, Biology and Impacts. Lewis Publishers, Boca Raton, pp. 315-343.

McMahon, R.F., 2002. Evolutionary and physiological adaptations of aquatic invasive animals: r selection versus resistance. Can. J. Fish. Aquat. Sci. 59, 1235-1244.

Ministério do Ambiente, 1998. Decreto-Lei n²36/98. Diário da República I Série A. pp. 3676-3722 (in Portuguese)

Modesto, V., Franco, J.N., Sousa, R., Patrício, J., Marques, J.C., Neto, J.M., 2013. Spatial and temporal dynamics of Corbicula fluminea (Müller 1774) in relation to environmenta variables in the Mondego Estuary (Portugal). J. Molluscan Stud. 79, 302-309.

Modesto, V., Ilarri, M., Souza, A.T., Lopes-Lima, M., Douda, K., Clavero, M., Sousa, R., 2018 Fish and mussels: importance of fish for freshwater mussel conservation. Fish Fish. 19, 244-259.

Neves, M.M.Y.R.J., Cherry, D.S., 1999. Competitive interactions between early life stages of Villosa iris (Bivalvia: Unionidae) and adult Asian clams (Corbicula fluminea). Proceedings of the First Freshwater Mollusk Conservation Society Symposium, pp. 253-259.

Neves, R.J., Widlak, J.C., 1987. Habitat ecology of juvenile freshwater mussels (Bivalvia: Unionidae) in a headwater stream in Virginia. Amer. Malac. Bull. 5 (1), 1-7.

Novais, A., Dias, E., Sousa, R., 2016. Inter- and intraspecific variation of carbon and nitrogen stable isotope ratios in freshwater bivalves. Hydrobiologia 765 $149-158$.

Phelps, H.L., 1994. The Asiatic clam (Corbicula fluminea) invasion and system-level ecological change in the Potomac river estuary near Washington, D.C. Estuaries 17, 614-621.

R Core Team, 2014. R: a language and environment for statistical computing. The R Foundation for Statistical Computing, Vienna, Austria Available online at. http://www.Rproject.org/ (ISBN 3-900051-07-0).

Rauch, G., Kalbe, M., Reusch, T.B.H., 2005. How a complex life cycle can improve a parasite's sex life. J. Evol. Biol. 18, 1069-1075.

Redner, B.D., Stickney, R.R., 1979. Acclimation to ammonia by Tilapia aurea. Trans. Am. Fish. Soc. 108 (4), 383-388.

Ricciardi, A., Whoriskey, F.G., Rasmussen, J.B., 1997. The role of the zebra mussel (Dreissena polymorpha) in structuring macroinvertebrate communities on hard substrata. Can. J. Fish. Aquat. Sci. 54, 2596-2608.
Ricciardi, A., Neves, R.J., Rasmussen, J.B., 1998. Impending extinctions of North American freshwater mussels (Unionoida) following the zebra mussel (Dreissena polymorpha) invasion. J. Anim. Ecol. 67, 613-619.

Roughgarden, J., Gaines, S., Possingham, H., 1988. Recruitment dynamics in complex life cycles. Science 241, 1460-1466.

Rowe, L., Ludwig, D., 1991. Size and timing of metamorphosis in complex life cycles: time constraints and variation. Ecology 72, 413-427.

Santos, R.M.B., Sanches Fernandes, LF, Varandas, S.G.P. Pereira, M.G, Sousa, R, Teixeira, A., Lopes-Lima, M., Cortes, R.M.V., Pacheco, F.A.L., 2015. Impacts of climate change and land-use scenarios on Margaritifera margaritifera, an environmental indicator and endangered species. Sci. Total Environ. 511, 477-488.

Scheller, J.L., 1997. The Effect of Dieoffs of Asian Clams (Corbicula fluminea) on Native Freshwater Mussels (Unionidae). Doctoral dissertation. Virginia Tech.

Sousa, R., Guilhermino, L., Antunes, C., 2005. Molluscan fauna in the freshwater tidal area of the River Minho estuary, NW of Iberian Peninsula. Ann. Limnol. Int. J. Limnol. 41, 141-147.

Sousa, R., Antunes, C., Guilhermino, L., 2008a. Ecology of the invasive Asian clam Corbicula fluminea (Müller, 1774) in aquatic ecosystems: an overview. Ann. Limnol. Int. J. Limnol. 44, 85-94.

Sousa, R., Dias, S., Freitas, V., Antunes, C., 2008b. Subtidal macrozoobenthic assemblages along the River Minho estuarine gradient (north-west Iberian Peninsula). Aquat. Conserv. 18, 1063-1077.

Sousa, R., Dias, S., Guilhermino, L., Antunes, C., 2008c. Minho River tidal freshwater wetlands: threats to faunal biodiversity. Aquat. Biol. 3, 237-250.

Sousa, R., Morais, P., Antunes, C., Guilhermino, L., 2008d. Factors affecting Pisidium amnicum (Müller, 1774: Bivalvia: Sphaeriidae) distribution in the River Minho estuary: consequences for its conservation. Estuar. Coasts 31, 1198-1207.

Sousa, R., Nogueira, A.J.A., Gaspar, M.B., Antunes, C., Guilhermino, L., 2008e. Growth and extremely high production of the non-indigenous invasive species Corbicula fluminea (Müller, 1774): possible implications for ecosystem functioning. Estuar. Coast. Shelf Sci. 80, 289-295.

Sousa, R., Rufino, M., Gaspar, M., Antunes, C., Guilhermino, L., 2008f. Abiotic impacts on spatial and temporal distribution of Corbicula fluminea (Müller, 1774) in the River Minho estuary, Portugal. Aquatic Conserv: Mar. Freshw. Ecosyst. 18, 98-110.

Sousa, R., Gutiérrez, J.L., Aldridge, D.C., 2009. Non-indigenous invasive bivalves as ecosystem engineers. Biol. Invasions 11, 2367-2385.

Sousa, R., Ilarri, M., Souza, A.T., Antunes, C., Guilhermino, L., 2011a. Rapid decline of the greater European peaclam at the periphery of its distribution. Ann. Limnol. Int. J. Limnol. 47, 211-219.

Sousa, R., Pilotto, F., Aldridge, D.C., 2011b. Fouling of European freshwater bivalves (Unionidae) by the invasive zebra mussel (Dreissena polymorpha). Freshw. Biol. 56, 867-876.

Sousa, R., Varandas, S., Cortes, R., Teixeira, A., Lopes-Lima, M., Machado, J., Guilhermino, L., 2012. Massive die-offs of freshwater bivalves as resource pulses. Ann. Limnol. Int. J. Limnol. 48, 105-112.

Sousa, R., Freitas, F.E.P., Mota, M., Nogueira, A.J.A., Antunes, C., 2013. Invasive dynamics of the crayfish Procambarus clarkii (Girard, 1852) in the international section of the River Minho (NW of the Iberian Peninsula). Aquat. Conserv. Mar. Freshwat. Ecosyst. 23, 656-666.

Sousa, R., Novais, A., Costa, R., Strayer, D.L., 2014. Invasive bivalves in fresh waters: impacts from individuals to ecosystems and possible control strategies. Hydrobiologia 735, 233-251.

Stoks, R., Córdoba-Aguilar, A., 2012. Evolutionary ecology of Odonata: a complex life cycle perspective. Annu. Rev. Entomol. 57, 249-265.

Strayer, D.L., 1999. Effects of alien species on freshwater mollusks in North America. J. North Am. Benthol. Soc. 18, 74-98.

Strayer, D.L., 2008. Freshwater Mussel Ecology: A Multifactor Approach to Distribution and Abundance. University of California Press, Berkley.

Strayer, D.L., Hattala, K.A., Kahnle, A.W., 2004. Effects of an invasive bivalve (Dreissena polymorpha) on fish in the Hudson River estuary. Can. J. Fish. Aquat. Sci. 61, 924-941.

Ueda, N., Richards, G.S., Degnan, B.M., Kranz, A., Adamska, M., Croll, R.P., Degnan, S.M., 2016. An ancient role for nitric oxide in regulating the animal pelagobenthic life cycle: evidence from a marine sponge. Sci. Rep. 6, 1-14.

Vaughn, C.C., Spooner, D.E., 2006. Scale-dependent associations between native freshwater mussels and invasive Corbicula. Hydrobiologia 568, 331-339.

Venables, W.N., Ripley, B.D., 2002. Modern Applied Statistics With S. fourth edition. Springer, New York.

Viergutz, C., Linn, C., Weitere, M., 2012. Intra- and interannual variability surpasses direct temperature effects on the clearance rates of the invasive clam Corbicula fluminea. Mar. Biol. 159, 2379-2387.

Vohmann, A., Borcherding, J., Kureck, A., Bij de Vaate, A., Arndt, H., Weitere, M., 2010. Strong body mass decrease of the invasive clam Corbicula fluminea during summer. Biol. Invasions 12, 53-64.

Wang, T.N., Augspurger, M., Barnhart, M.C., Bidwell, J.R., Cope, W.G., Dwyer, F.J., Geis, S., Greer, I.E., Ingersoll, C.G., Kane, C.M., May, T.W., Neves, R.J., Newton, T.J., Roberts, A.D., Whites, D.W., 2007a. Intra- and interlaboratory variability in acute toxicity tests with glochidia and juveniles of freshwater mussels (Unionidae). Environ. Toxicol. Chem. 26, 2029-2035.

Wang, N., Ingersoll, C.G., Hardesty, D.K., Ivey, C.D., Kunz, J.L., May, T.W., Dwyer, F.J., Roberts, A.D., Augspurger, T., Kane, C.M., Kane, C.M., Neves, R.J., Barnhart, M.C., 2007b. Acute toxicity of copper, ammonia, and chlorine to glochidia and juveniles of freshwater mussels (Unionidae). Environ. Toxicol. Chem. 26, 2036-2047.

Wang, N., Erickson, R.J., Ingersoll, C.G., Ivey, C.D., Brunson, E.L., Augspurger, T., Barnhart, M.C., 2008. Influence of $\mathrm{pH}$ on the acute toxicity of ammonia to juvenile freshwater 
mussels (fatmucket, Lampsilis siliquoidea). Environ. Toxicol. Chem. 27 (5), 1141-1146.

Werner, E.E., 1988. Size, scaling, and the evolution of complex life cycles. Size-Structured Popul, pp. 60-81.

Wilbur, H.M., 1980. Complex life cycles. Annu. Rev. Ecol. Evol. Syst. 11, 67-93.

Wilson, A.D.M., Krause, J., 2012. Metamorphosis and animal personality: a neglected opportunity. Trends Ecol. Evol. 27, 529-531.

Young, M., Williams, J., 1984. The reproductive biology of the freshwaterpearl mussel Margaritifera margaritifera in Scotland. I. Field studies. Arch. Hydrobiol. 99, 405-422.
Zhang, L., Gu, X.Z., Shao, S.G., Hu, H.Y., Zhong, J.C., Fan, C.X., 2011. Impacts of Asian clams (Corbicula fluminea) on lake sediment properties and phosphorus movement Huanjing Kexue 32, 88-95.

Zuur, A.F., Ieno, E.N., Walker, N.J., Saveliev, A.A., Smith, G.M., 2009. Mixed Effects Models and Extensions in Ecology With R. Springer, Berlin. 